\title{
The impact of entrepreneurship on economic, social and environmental welfare and its determinants: a systematic review
}

\author{
Thomas Neumann ${ }^{1}$ iD
}

Received: 21 May 2020 / Accepted: 19 July 2020 / Published online: 4 August 2020

(c) The Author(s) 2020

\begin{abstract}
This paper presents a systematic review of (a) the impact of entrepreneurship on economic, social and environmental welfare and (b) the factors determining this impact. Research over the past 25 years shows that entrepreneurship is one cause of macroeconomic development, but that the relationship between entrepreneurship and welfare is very complex. The literature emphasizes that the generally positive impact of entrepreneurship depends on a variety of associated determinants which affect the degree of this impact. This paper seeks to contribute to the literature in three ways. First, it updates and extends existing literature reviews with the recently emerged research stream on developing countries, and incorporates studies analysing not only the impact of entrepreneurship on economic growth and welfare but also on social and environmental welfare. Second, it identifies and structures the current knowledge on the determinants of this impact. And third, it provides a roadmap for future research which targets the shortcomings of the existing empirical literature on this topic. The review of 102 publications reveals that the literature generally lacks research which (a) goes beyond the common measures of economic welfare, (b) examines the long-term impact of entrepreneurship and (c) focuses on emerging and developing countries. Regarding the determinants of the impact of entrepreneurship, the results highlight the need for empirical research which addresses both already investigated determinants which require more attention (e.g. survival, internationalisation, qualifications) and those which are currently only suspected of shaping the impact of entrepreneurship (e.g. firm performance, the entrepreneur's socio-cultural background and motivations).
\end{abstract}

Electronic supplementary material The online version of this article (https://doi.org/10.1007/s1130 1-020-00193-7) contains supplementary material, which is available to authorized users.

Thomas Neumann

thomas.neumann@hs-flensburg.de

Extended author information available on the last page of the article 
Keywords Entrepreneurship - Startup · Employment · Economic development · Sustainable development $\cdot$ Developing countries

JEL Classification A12 $\cdot$ B55 $\cdot \mathrm{L} 26 \cdot \mathrm{M} 13 \cdot \mathrm{O} 40$

\section{Introduction}

Entrepreneurship and its possible impact on the economy have been studied extensively during the past two decades but the research field still continues to develop and grow. The majority of studies from a variety of scientific disciplines have found empirical evidence for a significant positive macroeconomic impact of entrepreneurship (e.g. Atems and Shand 2018; Audretsch and Keilbach 2004a; Fritsch and Mueller 2004, 2008). However, several empirical studies show that the macroeconomic impact of entrepreneurship can also be negative under certain conditions (e.g. Carree and Thurik 2008; Andersson and Noseleit 2011; Fritsch and Mueller 2004, 2008). Potential explanations for these contradictory results are to be found in the complex relationship between entrepreneurship and economic growth. Already some of the very first empirical studies on the macroeconomic impact of entrepreneurship showed that factors such as industrial affiliation (Fritsch 1996), the country's level of development and the local density of business owners (Carree et al. 2002) significantly determine the impact of entrepreneurship. With more entrepreneurship datasets becoming available, researchers found evidence that only a small number of new firms such as particularly innovative new firms and firms with high-growth expectations create economic value and initiate Schumpeter's process of 'creative destruction' (e.g. Szerb et al. 2018; Valliere and Peterson 2009; van Oort and Bosma 2013; Wong et al. 2005). However, over the past decade, researchers have identified a multitude of other relevant determinants (e.g. survival rates of new firms, institutional and cultural settings, motivations and qualifications of the entrepreneur), thereby drawing an increasingly complex web of interrelated determinants around the macroeconomic impact of entrepreneurship. This complexity combined with the fact that the research on determinants is scattered and mostly based on separate analyses of determinants leads to a number of hitherto unidentified research opportunities. In order to detect these opportunities and to exploit them in a targeted manner, a structured overview of the current knowledge on the determinants of the macroeconomic impact of entrepreneurship is required. In this context, a structured overview is not only essential for the scientific entrepreneurship community but also for politicians all over the world who need detailed information on the impact of entrepreneurship to promote the right types of entrepreneurship in the right situations.

To ensure that this information prepared for policy makers are truly comprehensive, it is essential that state-of-the-art research considers not only economic outcomes of entrepreneurship but also its social and environmental effects. This demand for a more holistic impact analyses is based on the call of economists who have been emphasizing since the 1970's that economic development may is a significant part of welfare, but that social and environmental dimensions need to be 
considered as well (Daly et al. 1994; Meadows et al. 1972; Nordhaus and Tobin 1972). Tietenberg and Lewis (2012, p. 553) summarised the economic, social and environmental effects in a holistic welfare definition and state that a "true measure of development would increase whenever we, as a nation or as a world, were better off and decrease whenever we were worse off'. This understatement is in line with many authors who recently highlighted the importance of entrepreneurship for social and environmental welfare (e.g. Alvarez and Barney 2014; Dhahri and Omri 2018; McMullen 2011). Entrepreneurship research has come to see entrepreneurs as a solution for social inequality and environmental degradation rather than a possible cause of them (Gast et al. 2017; Munoz and Cohen 2018; Terán-Yépez et al. 2020). This scientific consent of the past 50 years clearly illustrates how important it is that econometric research on entrepreneurship incorporates research on the economic as well as on the social and environmental impact of entrepreneurship. ${ }^{1}$

Considering that the research on the macroeconomic impacts of entrepreneurship has been gaining increasing recognition over the last two decades and across a wide range of disciplines (Urbano et al. 2019a), literature reviews must be conducted periodically to synthesize and reflect recent progress and to stimulate future research. Several high-quality reviews have already summarized the significant amount of research on the impact of entrepreneurship on the economy. Wennekers and Thurik (1999) were the first who discussed the link between entrepreneurship and economic growth in a narrative literature analysis. With their summary of the theoretical knowledge of that time and the first framework of the entrepreneurial impact the authors laid the groundwork for the following decade of empirical research on that matter. van Praag and Versloot (2007), extended that first review by systematically reviewing and evaluating the empirical findings of 57 articles published between 1995 and 2007. More precisely, the authors evaluated the various economic contributions of entrepreneurial firms, which have been defined by the authors as either employing fewer than 100 employees, being younger than 7 years or being new entrants into the market, relative to their counterparts. van Praag and Versloot (2007) thus made the first systematic attempt to distinguish the few new firms which are of economic relevance from the majority of meaningless new firms. Fritsch (2013), in a non-systematic monograph, exhaustively surveyed and assessed the then available knowledge on how new firms particularly effect regional development over time. Within this review, the author has established the term 'determinants' in the field of research on the impact of entrepreneurship and developed first suggestions on which factors may determine the impact of new firms. However, the author has not provided any empirical evidence for the effect of his proposed determinants. In contrast to these three literature reviews, the three most recent reviews also incorporated the latest findings from international studies and on developing countries.

\footnotetext{
1 For purposes of this study, the three welfare dimensions refer to the widely used definition of the three pillars of sustainable development (economic growth, social equality protection, environmental protection) of the Brundtland Report (World Development Commission on Environment and Development 1987). However, the reader should note that later sustainability models like the 'prism model' or the 'concentric circles model' illustrate that the three pillars of sustainable development (resp. the three welfare dimensions) are interlinked and not always clearly separable from one another.
} 
However, the three latest reviews all have a narrowly defined research focus. While Block et al. (2017; systematic literature review of 102 studies published between 2000 and 2015) analysed antecedents, behaviour and consequences of innovative entrepreneurship, Bjørnskov and Foss (2016; systematic literature review of 28 studies) and Urbano et al. (2019a; systematic literature review of 104 studies published between 1992 and 2016) focused on the relationship between the institutional context, entrepreneurship and economic growth. Accordingly, all the existing reviews are either (1) already outdated, (2) mostly on highly developed countries or (3) focused on specific topics. Furthermore, none of these reviews provided (4) a structured overview on the empirical knowledge on the impact of entrepreneurship on the economy or (5) included research on the social and environmental impact of entrepreneurship.

This paper addresses these five shortcomings through a comprehensive and systematic review of empirical research into the impact of entrepreneurship on economic, ${ }^{2}$ social and environmental welfare. The methodology of the review is based on the current knowledge of systematic reviews (e.g. Fayolle and Wright 2014; Fisch and Block 2018; Jones and Gatrell 2014; Tranfield et al. 2003), on narrative synthesis (e.g. Dixon-Woods et al. 2005; Jones and Gatrell 2014; Popay et al. 2006) and on recent examples of best practice (e.g. Jones et al. 2011; Urbano et al. 2019a; van Praag and Versloot 2007). Using this approach, this paper aims to contribute to the literature on the impact of entrepreneurship on welfare in three ways. First, it updates and extends the existing literature reviews. More specifically, it follows recent research recommendations (e.g. Block et al. 2017; Fritsch 2013; Urbano et al. 2019a) by incorporating the recent empirical stream of research on the impact of entrepreneurship in developing countries and research that goes beyond measures of common economic welfare. In practical terms, this means that this review not only considers measures of economic welfare (e.g. GDP, employment rates, innovative capacity), but also for social welfare (e.g. life expectancy, literacy rates, income inequality), for environmental welfare (e.g. $\mathrm{CO}_{2}$ emissions, water pollution, soil quality) and for indicators which incorporate all three welfare dimensions (e.g. Index of Sustainable Economic Welfare, Genuine Progress Indicator). Second, this paper, as demanded in previous reviews (Fritsch 2013; Urbano et al. 2019a), aims to provide a descriptive analysis of the factors determining the entrepreneurial impact by critically assessing (a) which determinants of the entrepreneurial impact have (b) what impact on (c) which measures of economic welfare. This paper thus represents the first comprehensive attempt to summarize and structure the empirical knowledge on the determinants of the impact of entrepreneurship. Finally, to encourage future research, this paper indicates shortcomings in the empirical research not only on the impact of entrepreneurship on economic, social and environmental welfare, but also on the described and structured determinants of this impact. It concludes with suggestions for future research avenues to close these research gaps.

\footnotetext{
${ }^{2}$ Although the author is fully aware of their different meanings, for simplicity, the more general term 'economic welfare' is used throughout this paper as synonymous with the terms 'economic growth' and 'economic development'.
} 
To achieve these objectives, this paper is structured as follows. Section 2 describes the methodological approach of the review. Sections 3.1 and 3.2 report the available empirical research into the impact of entrepreneurship on economic, social and environmental welfare. Section 3.3 summarizes the determinants of this impact and Sect. 4 presents a roadmap for future research. Section 5 discusses the limitations of this paper and provides a conclusion.

\section{Methodology}

In order to clarify not only the macroeconomic impact of entrepreneurship on economic welfare but also the determinants of this impact, this paper provides a broadranging systematic, evidence-based literature review including a narrative synthesis. According to Mulrow (1994), systematic reviews are particularly useful in identifying and evaluating a large volume of evidence published over a long period of time and have been frequently applied in recent state-of-the-art literature reviews (e.g. Li et al. 2020; Mochkabadi and Volkmann 2020; Urbano et al. 2019a). The systematic literature review conducted in this paper employs a rather broad empirical definition of entrepreneurship which covers both the entrepreneur, who creates or discovers new businesses (Kirzner 1973; Schumpeter 1942) and the entrepreneurial firm itself. Entrepreneurship is understood here as new business activity, which includes entrepreneurs in the process of new firm creation as well as recently founded firms. Furthermore, although not necessarily associated with the formation of new firms, self-employed individuals and owner-managers are defined here as entrepreneurs as well. This general definition is consistent with the majority of empirical studies (e.g. Bosma et al. 2011; Fritsch and Schindele 2011; Mueller et al. 2008). The review process comprises three major steps, namely (1) data collection, (2) the selection of relevant studies and (3) data synthesis.

\subsection{Data collection}

As a first step, to reduce bias and maintain objectivity in all stages of the review, a review panel was set up. The panel consists of the author, a professor and two doctoral students knowledgeable in this field of research. In order to obtain the most relevant terms for the systematic search, the suggestions of Tranfield et al. (2003) were followed and a number of scoping studies based on combinations of keywords related to the topic were performed. The insights from this initial search phase were used to further develop relevant search terms resulting in the Boolean search string presented in the online appendix. The number of selected search terms was intentionally rather broad to avoid overlooking potentially valuable studies. It included the most common terms and measures of entrepreneurship and of economic, social and environmental welfare. This search string was subsequently used to scan titles, abstracts, and enclosed keywords of studies in the electronic databases EBSCO Business Source Complete, ProQuest ABI/INFORM Global and Web of Science. These databases were selected, because they allow the application of complex search 


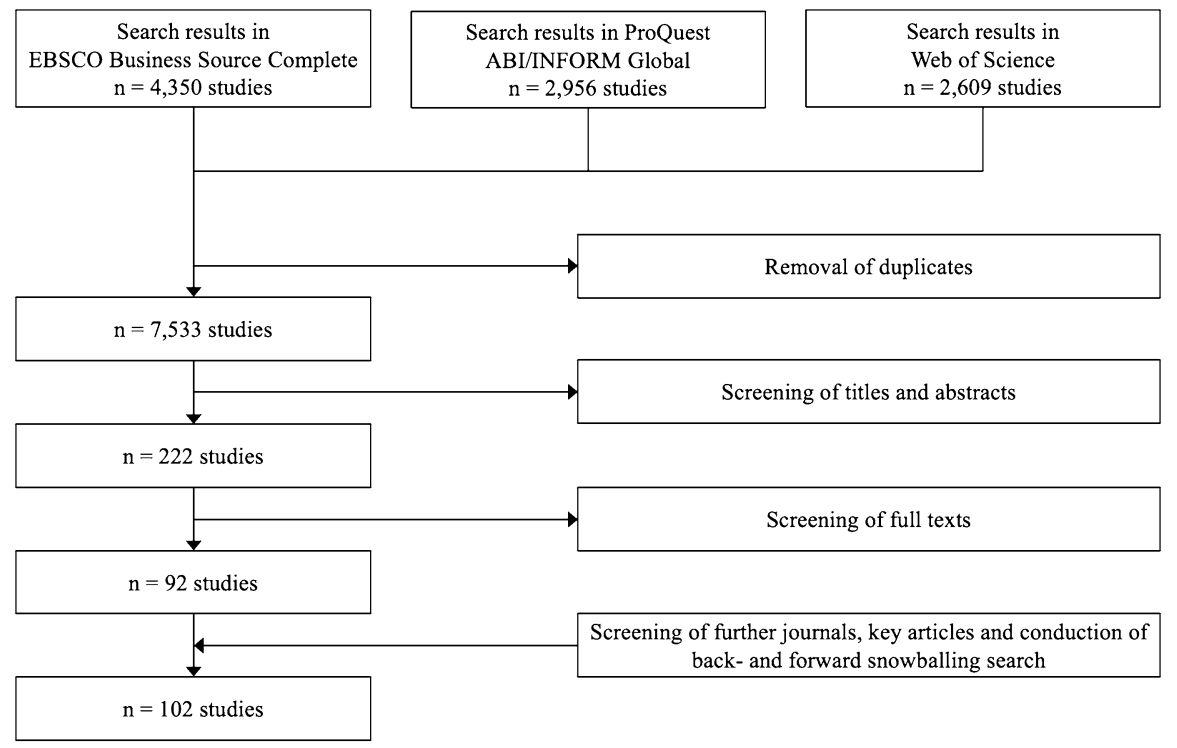

Fig. 1 Systematic process of data collection and selection

strings and cover an extensive range of scientific journals from a variety of different disciplines. In order to provide a quality threshold, only peer-reviewed journal articles were scanned, since they are considered as validated knowledge (Podsakoff et al. 2005; Ordanini et al. 2008). Unpublished papers, books, book chapters, conference papers and dissertations were omitted in the initial search. Furthermore, the search was restricted to studies written in English. The main search was conducted in May 2019 and updated once in December 2019. It yielded, after the removal of duplicates, an initial data set of $\mathrm{n}=7533$ studies.

In addition to the main search, three more steps were conducted to create an exhaustive sample. First, five journals of particular relevance for the discussion were manually searched. ${ }^{3}$ Second, meta-studies and literature reviews on related topics were screened for additional studies. ${ }^{4}$ And finally, based on the guidelines of Wohlin (2014), an iterative back- and forward snowballing approach was conducted. The whole process of data collection and selection and its results are summarized in Fig. 1.

\footnotetext{
${ }^{3}$ Namely: Regional Studies, Entrepreneurship \& Regional Development, The Annals of Regional Science, Economic Development Quarterly, Technological Forecasting and Social Change.

4 Namely: Bjørnskov and Foss (2016), Block et al. (2017), Fritsch (2013), Sutter et al. (2018), Urbano et al. (2019a), van Praag and Versloot (2007), Wennekers and Thurik (1999).
} 


\subsection{Data selection and quality assessment}

The studies collected during the main search were carefully reviewed to determine whether they were suitable for the objective of this paper. Titles, abstracts and, in doubtful cases, whole studies were checked against the following set of selection criteria.

1 Studies must analyse the macroeconomic impact of entrepreneurship by applying at least one economic, social or environmental welfare measure on an aggregated regional, national or global level.

2 Studies must employ definitions of entrepreneurship as discussed in the introduction of Sect. 2. Studies that solely analysed the impact of small firms, intrapreneurship, corporate-entrepreneurship, institutional entrepreneurship, or entrepreneurial capital were excluded.

3 Studies must apply adequate quantitative methods to measure the impact of entrepreneurship. Studies that only discuss this matter theoretically, that follow a qualitative approach or that do not go beyond simple correlation techniques were excluded.

4 Studies must analyse spatial units, as they seem to be considerably better suited to analysing the impact of entrepreneurship (Fritsch 2013). Studies that are based on the analysis of industry units were excluded.

5 Studies must analyse long-term panel data or data on an adequately aggregated level to account for demographic, political and economic events. Studies that analysed single spatial units over a short period of time were excluded.

Due to the broadness of the search string, the main search yielded many studies which solely dealt with the microeconomic performance of new firms or which analyse how the local level of development determines the number of new firms. Studies which were not related to the research questions or did not meet all five selection criteria, were manually removed. This process of selection in the main search led to a total of $n=92$ studies. The three additional search steps increased this number by $n=10$, resulting in a final data set of $n=102$ studies, including two high-quality book chapters which present empirical results of particular relevance to the paper's objective (namely Stam et al. 2011; Verheul and van Stel 2010). When comparing the sample size with that of related literature reviews, it appears to be appropriate. Hence, even if the selected sample is not exhaustive, it is very likely to be representative of the relevant literature.

\subsection{Data analysis}

Given that research in this area employs a variety of measures of entrepreneurship and of economic welfare and is methodologically diverse, it was unfeasible to perform a meta-analysis. Instead, an integrative and evidence-driven narrative synthesis based on the guidelines established by Popay et al. (2006) was chosen to aggregate, 
combine and summarise the diverse set of studies. Narrative synthesis is considered particularly useful when, as in this case, research area is characterised by heterogeneous methods, samples, theories, etc. (Fayolle and Wright 2014).

Once the final set of studies had been identified, the characteristics and study findings were extracted by carefully reading the methods and results sections. To reduce research bias, a review-specific data-extraction form was employed. The extraction-form is based on the suggestions of Tranfield et al. (2003) and Higgins and Green (2008) and contains general information, details about the analysed samples, the applied measures of entrepreneurship and economic welfare, the applied econometric techniques as well as short summaries of the relevant findings and the identified microeconomic impact factors.

\section{Results of the literature review}

The main results of the literature review regarding the impact of entrepreneurship on economic, social and environmental welfare and the determinants of this impact are presented in Table 5 (see online appendix). The large number of gathered studies on impact of entrepreneurship $(n=102)$ as well as on its determinants $(n=51)$ attest to the fact that this field of research has already been studied in great detail. Most of the identified studies were published in high-quality management, economics, social science and environmental science journals. Table 1 illustrates that the main part of the cross-disciplinary scientific discussion, however, took place in the Journals Small Business Economics (24\%) and Regional Studies (7\%). The number of empirical studies published per year has increased over the last decade, indicating the topicality of the research field and the need for an updated review of the new knowledge.

Figure 2 summarizes the statistics of the large amount of data gathered in Table 5 (see appendix) and illustrates the complexity of the research field. The left-handside lists the measures of entrepreneurship used in the analysed studies and shows how often they were applied. The most frequently applied measure of entrepreneurship is new firm formations either (a) per work force (labour market approach), (b) per number of existing firms (ecological approach) or (c) per capita. Another frequently applied measure of entrepreneurship is total early-stage entrepreneurial activity (TEA) based on data from the Global Entrepreneurship Monitor (Reynolds et al. 2003) or its subgroups: necessity-driven entrepreneurial activity (NEA), opportunity-driven entrepreneurial activity (OEA), innovative entrepreneurial activity (IEA) and high-growth expectation entrepreneurial activity (HEA). Other authors estimated regional entrepreneurship using self-employment or business ownership rates. The Kauffman Foundation Index for entrepreneurial activity is used less frequently, as it is a specific measure of entrepreneurship for US regions.

Regarding the right-hand-side of Fig. 2, it is noticeable that the majority of authors analysed the impact of entrepreneurship on economic welfare, primarily on GDP, growth and employment-related measures. Far fewer studies analysed the impact on the economic measures of national competitiveness or innovativeness, e.g. the number of patent applications. In contrast to the clear research focus on economic welfare, only five studies were found which analysed the impact of 


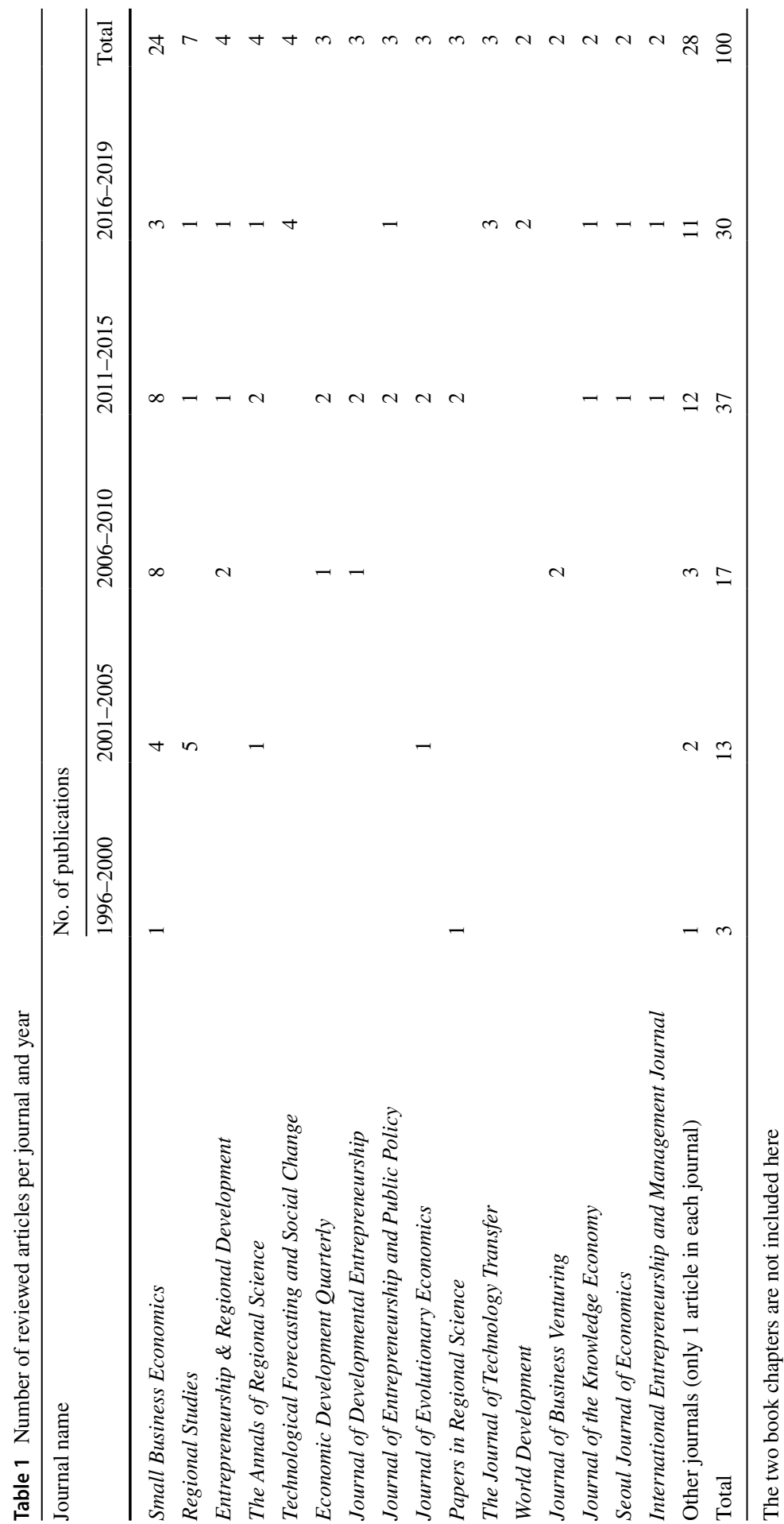




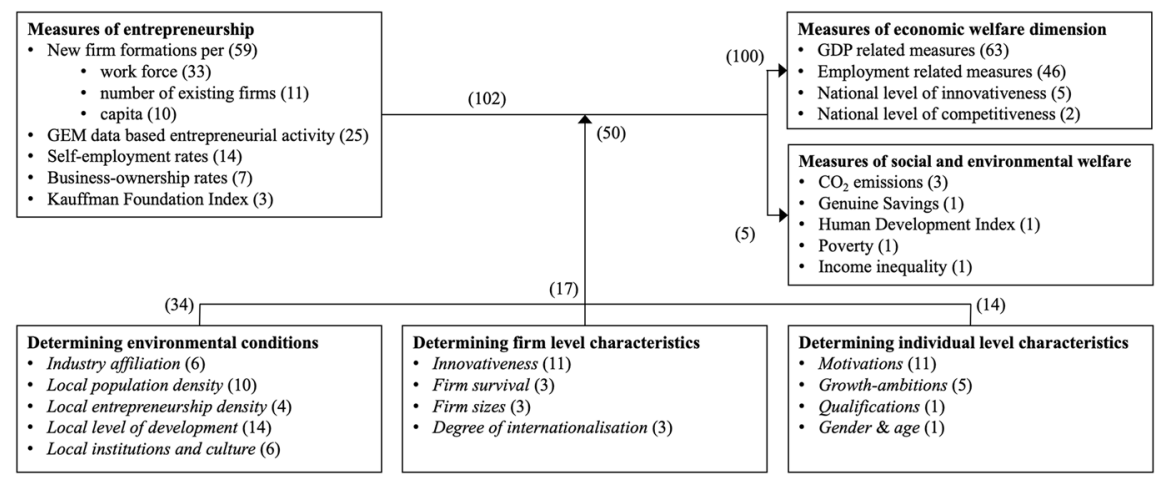

Fig. 2 Overview of applied measures of entrepreneurship and welfare, and analysed determinants. Note: the numbers in brackets represent the numbers of associated empirical studies

entrepreneurship on environmental or social welfare. Although many common measures of social and environmental welfare (e.g. crime rates or ecological footprint) were explicitly included in the search string (see online Appendix), no studies could be found that analyse the impact of entrepreneurship on them.

Independent of the measures of entrepreneurship and welfare used, the reviewed studies test their relationship by applying a very heterogenous set of methods. With the availability of more and more cross-sectional data covering longer and high-frequency time-series, authors started to apply new econometric approaches such as pooled and panel data regressions, fixed effect models, and subsequently, dynamic panel data models. Most authors based their analyses on rather straightforward regression techniques.

Sections 3.1 and 3.2 discuss empirical knowledge relating to the impact of entrepreneurship on economic welfare as well as on social and environmental welfare. Section 3.3 deals with the empirical evidence on the factors which determine this impact of entrepreneurship (see the lower part of Fig. 2).

\subsection{Impact of entrepreneurship on economic welfare}

The analysed literature predominantly confirms the results of previous literature reviews and gives empirical evidence that new firm formations have a generally positive effect on regional development and economic performance. The relationship holds for all tested measures of entrepreneurship and is robust across a broad range of spatial and cultural contexts.

The impact does, however, differ over time. Fritsch and Mueller (2004) studied the time-lag structure of the impact of entrepreneurship by applying an Almon lag model of different polynomial orders in their study of 326 West German regions. Their results revealed that the impact of entrepreneurship follows a typical timesequence: an S- or wave-shaped pattern which can be structured into three phases. Phase I is defined by a positive immediate increase of employment (direct effects of new capacities). After approximately 1 year, in phase II, this positive short-term 
Table 2 Number of studies per phase and measured impact

\begin{tabular}{llll}
\hline $\begin{array}{l}\text { Measures of economic } \\
\text { welfare }\end{array}$ & \multicolumn{2}{l}{ No. of publications } \\
\cline { 2 - 4 } & Negative & Neutral & Positive \\
\hline Short-term (I) & & 6 & 31 \\
Employment & 2 & 9 & 45 \\
GDP related & & & \\
Medium-term (II) & 16 & 3 & 12 \\
Employment & 2 & 2 & 15 \\
GDP related & & & \\
Long-term (III) & & 2 & 22 \\
Employment & & 1 & 10 \\
GDP related & & & \\
\hline
\end{tabular}

impact becomes smaller, insignificant or even negative (displacement effects and market selection). Around year five, this medium-term impact becomes positive again and reaches a peak in year eight (supply-side and spill-over effects). This positive long-term effect of entrepreneurship on employment, which defines phase III, diminishes after a period of 10 years.

Table 2 presents the findings of all reviewed studies which analysed the impact of new firm formations on employment and GDP in one, two or all three phases. It shows that the findings regarding the impact of entrepreneurship on employment are largely consistent with the wave-pattern theory. The existence of the wave-pattern could be confirmed on different regional levels for Great Britain (Mueller et al. 2008), for the United States (Acs and Mueller 2008; Henderson and Weiler 2009), for Portugal (Baptista et al. 2008; Baptista and Preto 2010, 2011), for West Germany (Fritsch and Mueller 2008; Fritsch and Noseleit 2013a), for the Netherlands (van Stel and Suddle 2008; Koster 2011; Delfmann and Koster 2016), for Sweden (Andersson and Noseleit 2011), for China (Rho and Gao 2012) for Canada (Matejovsky et al. 2014) as well as in several cross-country studies on OECD countries (Audretsch et al. 2015; Carree and Thurik 2008; Koellinger and Thurik 2012; Thurik et al. 2008). Furthermore, the reviewed studies reveal that this relationship not only holds for new firm formations as a measure of entrepreneurship but also for self-employment (e.g. Matejovsky et al. 2014; Rho and Gao 2012; Thurik et al. 2008) and business ownership (e.g. Carree and Thurik 2008; Henderson and Weiler 2009; Koellinger and Thurik 2012). The latter two measures of entrepreneurship, however, seem to have a less pronounced impact (Acs and Armington 2004; Rho and Gao 2012; Dvouletý 2017). Empirical evidence suggests a similar wave-pattern for the impact of entrepreneurship on GDP. Studies on GDP analysing all three phases confirm the positive short- and long-term peaks. However, in contrast to the results on employment, they find the medium-term impact to be less pronounced and positive (Audretsch et al. 2015; Carree and Thurik 2008; Koellinger and Thurik 2012; Matejovsky et al. 2014). The few empirical results displayed in Table 2, which contradict the wave-pattern theory (e.g. findings of a negative short-term impact of entrepreneurship on GDP), can largely be explained by certain determining factors 
such as a differing impact in developing countries (see Sect. 3.3.4) or of necessitydriven entrepreneurship (see Sect. 3.3.9).

The results for other measures of economic welfare are scarce and contradictory. Ferreira et al. (2017) analysed the short-term impact of entrepreneurship on different measures of competitiveness and found that TEA and IEA positively related to competitiveness. However, they found no significant relationship between OEA and competitiveness. On the contrary, a study by Mrozewski and Kratzer (2017) found a positive relationship between OEA and competitiveness, but not between TEA and competitiveness.

The empirical results regarding the impact of entrepreneurship on innovativeness are also inconclusive. Acs and Varga (2005) and Draghici and Albulescu (2014) found that OEA has a positive impact on patent applications and innovation indices, but that TEA and NEA do not have any significant impact on them. Anokhin and Wincent (2012) found a positive impact of TEA on innovativeness but a more recent study from Albulescu and Draghici (2016) found that neither TEA nor OEA have a significant relationship to innovativeness. Similarly, Cumming et al. (2014) found new firm formations based on the labour market approach have a positive shortterm impact on patent applications, but new firm formations based on the ecological approach and business ownership rates do not.

\subsection{The impact of entrepreneurship on social and environmental welfare}

Contrary to the well-researched impact of entrepreneurship on employment and GDP, little is known about the impact on social and environmental welfare. Three independent studies recently found empirical evidence that entrepreneurship positively affects measures of social welfare. Rupasingha and Goetz (2013) found that in the short-term self-employment reduces poverty in rural and urban U.S. counties, Atems and Shand (2018) found that in the medium-term self-employment decreases income inequality in U.S. states and, finally, Dhahri and Omri (2018) found new firm formations to increase the national modified Human Development Index (MHDI) in developing countries.

The empirical research on the impact of new firm formations on environmental welfare, however, illustrates that entrepreneurship may also come with major drawbacks. Omri (2017) as well as Dhahri and Omri (2018) and Ben Youssef et al. (2018) found that new firms significantly increase the amount of national $\mathrm{CO}_{2}$-emissions. According to Ben Youssef et al. (2018), this unfortunate impact on $\mathrm{CO}_{2}$-emissions is in fact so great that, despite the positive impact on GDP, new firms decrease Genuine Savings (also known as adjusted net saving) in African countries. They also found that the impact is more pronounced for informal new firm formations. This finding matches the results of Omri (2017), who detected the impact on $\mathrm{CO}_{2}$-emissions to be lower in developed countries which generally have lower rates of informal entrepreneurship (Williams and Lansky 2013). Furthermore, Omri (2017) discovered that the relationship between new firm formations and $\mathrm{CO}_{2}$-emissions is not linear but can be described as exhibiting an inverted U-shape. Thus, at an already high level of entrepreneurship, new firm formations may result in a decrease in $\mathrm{CO}_{2}$-emissions. 


\subsection{Determinants of the impact of entrepreneurship}

So far, the empirical results suggest, in many cases, a clear causal macroeconomic impact of new firm formations on economic measures of welfare. However, this topic is reasonably complex, and the complexity increases further when determining factors of this impact are considered. The lower part of Fig. 2 presents an overview of the empirical knowledge on these determinants. A key finding of this review, namely that all of the found analyses of determinants focus exclusively on the economic effects of entrepreneurship, is, however, not illustrated in Fig. 2. The review revealed that, although they are strongly interdependent, the determinants of the impact of entrepreneurship can generally be categorized into external environmental conditions, firm level characteristics and individual characteristics of the entrepreneurs themselves. Figure 2 illustrates that most empirical research has been conducted on the determining environmental conditions and on the firm level characteristic innovativeness and on the individual level characteristic motivations. In fact, some of the determinants presented have already been thoroughly investigated in highly recommendable earlier literature reviews, namely: industry affiliation (Fritsch 2013), regional population- and entrepreneurship density (Fritsch 2013), institutions and culture (Bjørnskov and Foss 2016; Urbano et al. 2019a), innovativeness (Block et al. 2017). The review for this paper confirms these findings and briefly summarizes the key learnings in the Sects. 3.3.1 to 3.3.3 and 3.3.5. However, except for a recently emerged empirical research stream on innovativeness, no new insights could be gained on the already reviewed determinants. Therefore, the focus of this section is primarily on the empirical evidence which has not yet been systematically investigated.

\subsubsection{Industry affiliation}

Fritsch (1996) was one of the first to analyse how entrepreneurial impact differs between industries. He focused on the impact of new firm formations on employment in West Germany and found it to be significantly higher in the manufacturing sector than in the service sector. Several authors confirmed this finding for the Netherlands (van Stel and Suddle 2008), for West-Germany (Fritsch and Mueller 2004) and for Sweden (Andersson and Noseleit 2011). Other studies, however, found the impact of new firms on economic welfare measures to be higher in the service sector (Bosma et al. 2011; Koster and van Stel 2014). Fritsch (2013) reasoned that these contradicting results may be due to considerable differences between the industries in different regions or countries and thus an analysis at the industry level might be not appropriate at all. For more information on the industrial perspective of the entrepreneurial impact on the economy, Fritsch (2013) provides a comprehensive overview including policy implications and avenues for further research.

\subsubsection{Regional population- and entrepreneurship density}

In a second wave of literature, researchers analysed how the impact of entrepreneurship differs between regions. They found clear evidence that the magnitude of the 
entrepreneurial impact is positively related to the population density (Baptista and Preto 2011; Fritsch and Mueller 2004, 2008; Fritsch and Schroeter 2011; Henderson and Weiler 2009; Lee 2017; Li et al. 2011; van Stel and Suddle 2008). In urban regions and agglomerations, new firms have a more pronounced and more positive impact on employment (Baptista and Preto 2011; Henderson and Weiler 2009; van Stel and Suddle 2008) and GDP (Audretsch et al. 2015; Belitski and Desai 2016) throughout all three previously described phases (see Sect. 3.1). On the contrary, in rural and less agglomerated regions, the entrepreneurial impact is weak and often negative (Fritsch and Mueller 2004, 2008).

While the economic relevance of new firm formations seems to increase with the population density, empirical evidence suggests that this is not the case for the relation between firm formations and regional entrepreneurship density. On the contrary, several authors found that the economic effect of another new firm becomes lower the more entrepreneurs are already on the market and even zero for regions with high entrepreneurship rates close to equilibrium rate (e.g. Carree et al. 2002, 2007; Mueller et al. 2008). These empirical insights identify entrepreneurship as a regional phenomenon and illustrate that macroeconomic effects of new firms are shaped by local conditions. An in-depth discussion of regional differences in the macroeconomic impact of new firms can be found in the monograph by Fritsch (2013).

\subsubsection{Institutions and culture}

To shed light on the complex interactions between institutions, entrepreneurship and economic growth, Urbano et al. (2019a) and Bjørnskov and Foss (2016) recently conducted thorough literature reviews. The empirical evidence identified in the present paper (Aparicio et al. 2016; Audretsch and Keilbach 2004a, b, c; Bjørnskov and Foss 2016) is in line with the findings of these two reviews which suggest that institutions affect the economy indirectly through endogenous factors like entrepreneurship. This holds true for formal institutions like (academic) support systems for new firms, procedures and costs to create a business, property rights or political structures as well as for informal institutions like social norms, cultures or belief systems (Urbano et al. 2019a). However, in contrast to Bjørnskov and Foss (2016), Urbano et al. (2019a) suggest that formal and informal institutions are not of equal importance, but that social norms and cultures have higher and more positive effects on the relation between entrepreneurship and economic growth.

\subsubsection{Local level of development}

While Sect. 3.1 illustrates that the impact of entrepreneurship in developed countries follows a typical wave-pattern, until now, no studies have analysed this time-pattern in developing countries. In general, the empirical evidence on the impact in developing countries is contradictory: some studies found a positive impact of entrepreneurship (Ben Youssef et al. 2018; Dhahri and Omri 2018; Feki and Mnif 2016; Stam et al. 2011), others found no or even a negative impact (Anokhin and Wincent, 2012; Ferreira et al. 2017; Verheul and van Stel 2010). However, studies which compared countries in different development stages found that the magnitude of the impact of 
entrepreneurship depends on the national welfare level and is generally higher in more developed countries (Anokhin and Wincent 2012; Carree et al. 2002, 2007; Crnogaj et al. 2015; Hessels and van Stel 2011; Urbano and Aparicio 2016; Valliere and Peterson 2009; van Stel et al. 2005; Verheul and van Stel 2010). Furthermore, little is known on the mechanisms behind the impact of entrepreneurship in developing countries. Most of the few studies which specifically deal with developing countries $(n=19)$ analysed the impact on a national level $(n=16)$ based on GEM data $(n=12)$, focused on the impact on GDP related measures $(n=17)$, or solely analysed the short- or medium-term impact $(n=16)$.

\subsubsection{Innovativeness}

According to the knowledge spillover theory of entrepreneurship, new knowledge results in business opportunities and entrepreneurs exploit these opportunities by turning the new knowledge into innovative products (Acs et al. 2009, 2013; Audretsch and Keilbach 2005). Recent studies confirm this theory and provide empirical evidence that entrepreneurship moderates the transformation of new knowledge into innovations (Block et al. 2013) and that innovative regions with higher levels of entrepreneurship perform economically better (González-Pernía et al. 2012). Accordingly, it is reasonable to assume that particularly innovative new firms are more important to economic welfare than their non-innovative counterparts. These considerations coincide with those presented in the literature review on innovative entrepreneurship by Block et al. (2017). However, the present systematic literature review extends the review of Block et al. (2017) by including previously unconsidered as well as recently emerged empirical evidence on the macroeconomic impact of innovative entrepreneurship. The identified empirical studies do indeed confirm the presumed positive impact of innovativeness. Crnogaj et al. (2015) as well as Du and O'Connor (2017) and Szerb et al. (2018) used GEM data to compare the impact of founders who stated their products or services to be new or at least unfamiliar to their customers. All of the previously mentioned authors found that innovative founders have a higher impact on GDP, economic efficiency, gross value added (GVA) and employment than less innovative founders. Furthermore, earlier studies attest to new firms which are in innovative, knowledge- or technology-intensive industries a higher than average impact on both GDP (Audretsch and Keilbach 2004a, b, 2005, Mueller 2007) and employment (Baptista and Preto 2010, 2011).

\subsubsection{Firm survival}

Empirical evidence suggests that a particularly important determinant of the impact of entrepreneurship is whether new firms are able to survive the first years. Falck (2007) was the first to find empirical evidence of a positive relationship between new firms which survive for at least 5 years and efficiency of the industry in which they are in. On the contrary, he could not find any significant relationship to industry level efficiency growth for firms which did not survive the first 5 years. Brixy (2014), Fritsch and Noseleit (2013b) and Fritsch and Schindele (2011) have confirmed that 
Falck's (2007) findings not only hold for the relationship between entrepreneurship and GDP but also for the relationship between entrepreneurship and employment.

\subsubsection{Firm size}

Baptista and Preto (2010) found that new firms of a larger than average initial size have a strong impact on employment and that this impact follows a pronounced wave-shaped time-lag structure (see Sect. 3.1). New firm formations which are smaller than average, on the other hand, only have a small impact. Acs and Mueller (2008) confirmed this finding and show that small new firms have a positive but declining direct impact on employment. The impact of medium and large new firms, however, is much higher and increases till it peaks in year five. Very large new firms (>499 employees), however, decrease employment in the short- and medium-term, probably due to restructuring processes of incumbents. This empirical evidence suggests that up to a threshold, large new firms have a larger impact on employment.

\subsubsection{Degree of internationalization}

A less studied but yet empirically significant determinant is a firm's degree of internationalization. Baptista and Preto (2010) analyzed 30 Portuguese regions and found that new firms which were, at least, partially owned by foreign investors had a much higher and more pronounced medium- and long-term impact on employment. A second measure of the positive impact of internationally active new firms is the export-orientation of new firms. Hessels and van Stel (2011) compared the impact of total-entrepreneurial activity and export-driven entrepreneurial activity on GDP per capita in 34 developed and developing countries. They found evidence that new firms for which the share of customers living abroad is above $26 \%$ have a more positive impact on GDP_-but only in developed countries. González-Pernía and PeñaLegazkue (2015) confirmed their finding on a regional level by comparing OEA and export-oriented OEA in 17 Spanish regions. Besides a generally higher impact of export-oriented new firms, González-Pernía and Peña-Legazkue (2015) found that the impact increases with higher shares of foreign customers up to a threshold level. An earlier study by Fryges and Wagner (2008), who found a positive relationship between firm-level productivity and export-sales ratio, supports the evidence for a more positive impact of internationally active new firms.

\subsubsection{Motivation}

The literature review conducted for this paper provided eleven studies which empirically tested the macroeconomic importance of the entrepreneur's motivations. All of these studies applied GEM-based data and definitions for opportunity-driven entrepreneurial activity (OEA) and necessity-driven entrepreneurial activity (NEA). Although four of these studies could not find a significant economic impact of OEA or NEA (Albulescu and Draghici 2016; Ferreira et al. 2017; Valliere and Peterson 2009; Wong et al. 2005), the other seven studies found evidence that OEA significantly increases national innovativeness (Acs and Varga 2005; Draghici and 
Albulescu 2014), competitiveness (Mrozewski and Kratzer 2017) and productivity (Du and O'Connor 2017; González-Pernía and Peña-Legazkue 2015; IvanovicĐukic et al. 2018; Urbano and Aparicio 2016). Moreover, six of these seven studies confirmed that the impact of OEA is higher compared to NEA and TEA. Mrozewski and Kratzer (2017) even found NEA to decrease the national competitiveness.

\subsubsection{Growth-ambitions}

There are some entrepreneurs who not only seek to exploit a business-opportunity but also have high growth-ambitions for their new firms. All five empirical studies selected for this paper take GEM data on high-growth expectation entrepreneurship (HEA) as a measure of the entrepreneur's growth-ambitions and found that it has a significantly positive impact on GDP-related measures of welfare. Furthermore, the impact of HEA seems to be more positive compared to TEA, to NEA and even to OEA (Ivanović-Đukić et al. 2018; Stam et al. 2011; Valliere and Peterson 2009; Wong et al. 2005). Generally, this macroeconomic impact of HEA seems to increase with the level of growth-aspiration (van Oort and Bosma 2013). The positive impact of HEA on economic welfare could be confirmed on the regional- and nationallevel as well as for developed countries. For less-developed countries, however, the empirical evidence is contradicting. On the one hand, Valliere and Peterson (2009) only found a significant impact of HEA on GDP for 25 developed countries, but not for the 18 emerging countries. On the other hand, Stam et al. (2011) found the impact of HEA on GDP in eight analysed lower-income to upper-middle-income economies (World Bank 2002 classification) even higher compared to the impact in the 22 analysed high-income economies.

\subsubsection{Qualification}

While many microeconomic studies have highlighted that an entrepreneur's qualifications in terms of education (e.g. Kangasharju and Pekkala 2002), skills and experience (e.g. Brüderl et al. 1992; Baum et al. 2001; Unger et al. 2011) play a significant part in the success of new firms, only one of the studies empirically investigated the macroeconomic impact of education. This is an analysis of 3702 German firms conducted by Engel and Metzger (2006). It suggests that new firms founded by people with an academic degree may have a more positive direct employment effect, than firms founded by people without an academic degree. This finding is, however, based on an old dataset (1990-1993) and a simple descriptive comparison and the authors did not apply control variables such as the regional density of more educated people.

\subsubsection{Gender and age}

Only one study could be found which empirically analysed the economic impact of the entrepreneur's gender and age. This study was conducted by Verheul and van Stel (2010) and was based on a dataset of 36 developed and developing countries. Their results show that there is a positive relationship between young opportunity-driven 
entrepreneurs between the ages of 18 and 24 and national GDP growth in developed countries, while in developing countries there is only a significant positive relationship between entrepreneurs aged between 45 and 64 and GDP growth (Verheul and van Stel 2010). Contrary to the microeconomic literature (e.g. Cliff 1998; Kalleberg and Leicht 1991; Rosa et al. 1996), Verheul and van Stel (2010) could not find any significant gender differences on the macroscale.

\section{Roadmap for further research}

The major scientific value and contribution of this paper lies in the groundwork for future research. Despite the extant of the reviewed existing research, many questions still remain unanswered. The following two sections therefore highlight the shortcomings of current research and make suggestions on how to address them. Section 4.1 discusses how remaining gaps in empirical research into the impact of entrepreneurship can be addressed and Sect. 4.2 presents fruitful research avenues on the determinants of the impact of entrepreneurship.

\subsection{Implications for future research on the impact of entrepreneurship}

\subsubsection{More variety in the measures of entrepreneurship}

A high variety of measures of entrepreneurship is required to test the robustness of results but international comparative studies, in particular, are mainly based on just two entrepreneurship datasets: Comparative Entrepreneurship Data for International Analysis (COMPENDIA) based on OECD statistics and data from the GEM research project. The use of a high variety of entrepreneurship definitions and measures of entrepreneurship across studies makes it difficult to compare the results of these studies. While some studies simply estimate entrepreneurship based on self-employment rates or business-ownership rates, others measure entrepreneurship by counting new firm formations and firm exits or use holistic measures based on, e.g., Schumpeter's understanding of entrepreneurship.

In order to test the robustness of the results and, at the same time, to allow for comparability between different studies, researchers should employ not one but multiple common measures of entrepreneurship in future studies. To make this possible, policy makers need to encourage the creation of internationally harmonized entrepreneurship databases. Furthermore, due to the limited availability of entrepreneurship data, only a few empirical studies have made a distinction between different types of entrepreneurship. That is why, as recommended by many researchers before (e.g. Baptista and Preto 2011; Fritsch and Schroeter 2011; Urbano et al. 2019a), this study calls for more diversity in the application of measures of entrepreneurship. 


\subsubsection{Implementation of measures of social and environmental welfare}

Section 3.1 revealed that $95.1 \%$ of the examined empirical studies only analysed the impact of entrepreneurship on economic welfare. Politicians who have no information on the impact of entrepreneurship on social and environmental welfare and thus solely rely on this economic information, however, may implement unsustainable development strategies (Tietenberg and Lewis 2012). Indeed, the few empirical studies $(n=5)$ which go beyond a traditional economic analysis indicate that entrepreneurship also has a significant contribution to measures of social and environmental welfare such as $\mathrm{HDI}, \mathrm{CO}_{2}$ emissions or poverty, which must not be neglected by politicians and researchers alike. To fill the immense gap in research on the impact of entrepreneurship on social and environmental welfare, two simultaneous approaches are proposed. First, as mentioned before, future research should generally include a variety of dependent welfare variables - social and environmental as well as economic ones. Second, future research should adopt research designs that have already proved effective in the macroeconomic impact analysis to answer novel research questions that address the impact of entrepreneurship on social and environmental welfare. The required methods for such analyses have been tested many times and, at least at national level, data availability poses no problem. Most countries have not only been collecting specific social and environmental welfare data for many years, but also established more holistic measures of welfare such as the Index of Sustainable Economic Welfare. Accordingly, it is up to the research community to break with traditions and expand the field of research by analysing social and environmental welfare rather than just economic welfare.

\subsubsection{More research on developing countries}

Section 3.3.4 illustrated that the local level of development is a relevant determinant of the impact of entrepreneurship. Nevertheless, most of the research reviewed for this paper focused solely on developed countries. This can partly be explained by the fact that most of the authors of these studies are based in Europe and the US, as well as by the lack of adequate long-term data for developing countries. However, this has begun to change. In the past 5 years, the number of empirical studies on developing countries has more than doubled to $n=30$. Nevertheless, regional-level studies as well as long-term studies for developing countries remain scarce. Because of the growing importance of developing and particularly BRICS countries, it is important to increase the knowledge on how the impact of entrepreneurship manifests in these countries.

\subsubsection{More studies on the lag-structure of the impact of entrepreneurship}

Section 3.1 illustrates that although the important indirect impact of entrepreneurship requires 5 or more years to unfold, most empirical research focuses on the direct short-term impact. Neglecting the long-term effects of entrepreneurship therefore results in an incomplete picture. Furthermore, the analysis of longitudinal data is required to conduct relevant causality tests. So far, the bottleneck for national-level 
long-term studies has been the lack of longitudinal data. But, due to more than 20 years of worldwide data collection for the GEM, there is now at least one sufficiently large entrepreneurship database. In line with other authors who have recognised this issue (e.g. Baptista et al. 2008; Carree and Thurik 2008; Fritsch 2013), this paper recommends that all future research should analyse not only the shortterm but also the medium- and long-term impact of entrepreneurship.

\subsection{Implications for future research on determinants}

Table 3 summarizes key statistics for the determinants in the research reviewed for this paper. Comparing the last two rows, it seems that the studies analysing the determinants of the impact of entrepreneurship are a representative share of all reviewed studies. For this reason, the previously presented suggestions for future research also apply to literature on the determinants. On closer examination, however, Table 3 reveals further and more precise research gaps. These include, inter alia, the need to study particularly the environmental and firm level determinants in developing countries, and the analysis of individual level determinants in combination with the lag-structure of the impact of entrepreneurship. The requirement for more long-term studies is further highlighted here. This finding further specifies the previous call for more long-term studies. The following subsections present further research and research implications.

\subsubsection{More variety in measures of entrepreneurship}

Table 3 shows that research on environmental and firm level determinants are mainly based on new firm formations as a measure of entrepreneurship, and research on individual level determinants almost solely measures entrepreneurship using GEM data.

The only exceptions are studies on the determinants local level of development-which are comparing the entrepreneurial impact across countries and thus are also mostly based on GEM data-and on innovativeness. None of the studies on the determinants apply self-employment (for the sake of clarity not presented in Table 3) to estimate entrepreneurship. This illustrates that the research on all individual determinants, except for innovativeness, considerably lacks variety when it comes to the applied measures of entrepreneurship.

\subsubsection{More variety in measures of welfare}

In addition to the fact that there are no studies examining the determinants of the impact of entrepreneurship on social or environmental welfare, there is also a lack of variety in the studies of measures of economic welfare. Studies on all individual level determinants and particularly on the determinant local level of development almost exclusively analyse the impact of entrepreneurship on GDP-related measures of welfare. Studies on the determinants industry affiliation, population density, firm survival and firm size mainly analyse employment effects of entrepreneurship. Other 


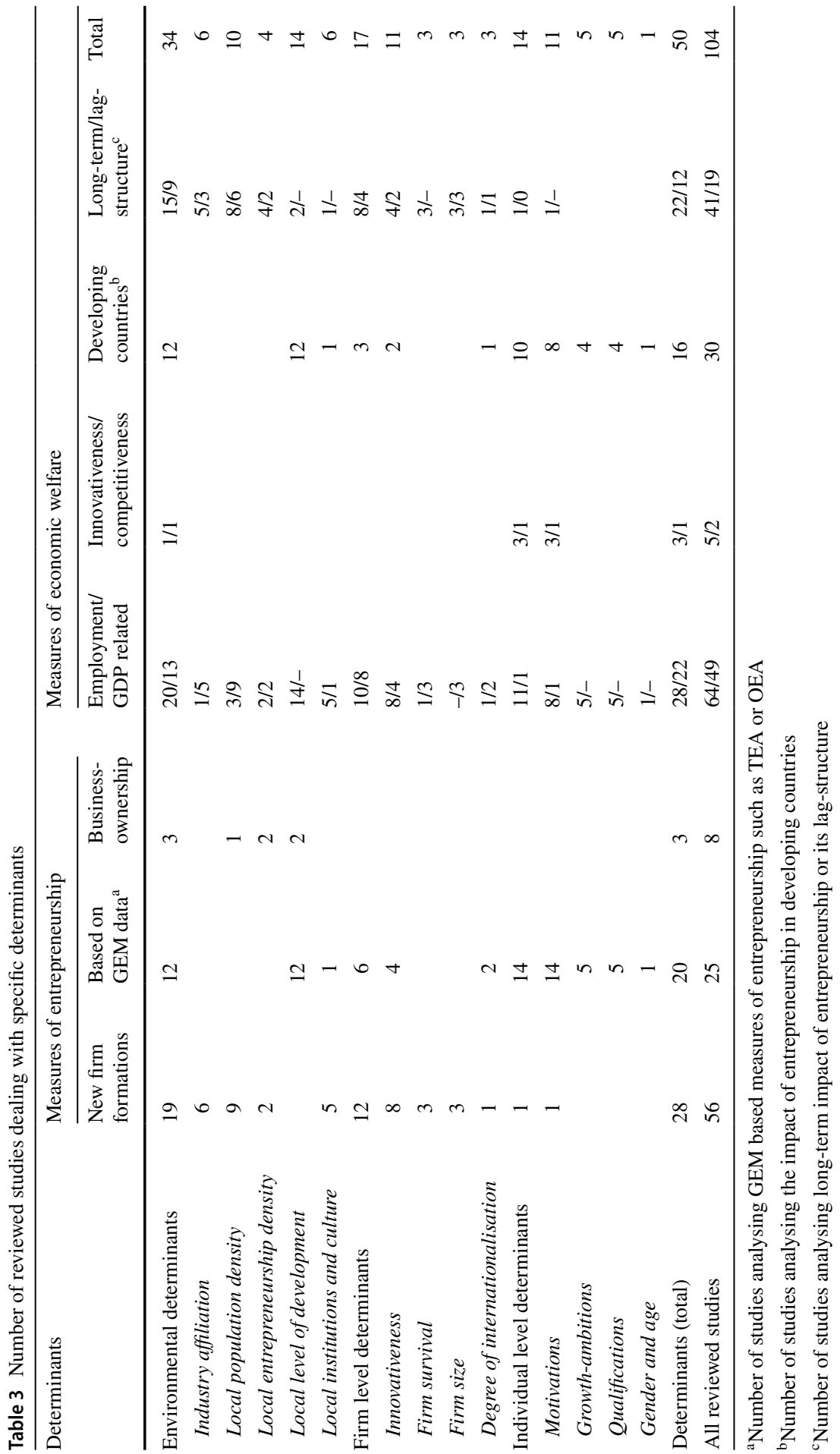


common measures of economic welfare, such as innovativeness or competitiveness, are rarely studied and need further investigation.

\subsubsection{Further research on determinants}

Table 3 illustrates that the existing research is imbalanced and that it pays varying degrees of attention to individual determinants. Determinants such as innovativeness, motivations and most environmental level determinants have so far received a great deal of attention, while others have only been analysed in very few studies. However, some of these poorly researched factors promise to be relevant determinants. More specific, the few existing empirical results analysing firm survival, degree of internationalisation and growth-ambitions suggest that these determinants have a comparatively high effect on the relationship between entrepreneurship and economic welfare. Furthermore, these determinants as well as the largely unexplored determinant qualifications are of considerable practical and political relevance. More empirical research on these determinants and their moderating role is required to improve incentives and support programs for entrepreneurs.

\subsubsection{New research focus on determinants not yet empirically investigated}

Table 4 provides a short overview of determinants which are likely to shape the entrepreneurial macroeconomic impact, but which have not yet been empirically investigated. They are a selection of indicators which are believed to determine the impact of entrepreneurship on economic welfare or which are empirically related to the success and survival of new firms and thus are also likely to be of macroeconomic importance. The overview is based on a non-systematic scan of the microeconomic literature and makes no claim to completeness. Due to their particularly high microeconomic relevance highlighted by the authors listed in Table 4, this paper specifically proposes additional research on how firm performance, organisational structure and strategies, networking activities and motivations (beyond necessity and opportunity entrepreneurship) determine the impact of entrepreneurship.

\subsubsection{Methodological recommendations}

Many of the determinants discussed here are highly interdependent, which makes it very difficult to extract and examine their separate effects. Individual level characteristics and environmental conditions are especially likely to affect the impact of entrepreneurship mainly indirectly through firm performance. The complexity is increased further as determinants may be indicators for other macroeconomically relevant effects. For instance, the numbers of highly innovative new firms and of highly qualified entrepreneurs may be positively correlated with the excellence of the regional educational infrastructure. This in turn could mean that the excellence of educational infrastructure is the true reason for economic growth and innovative new firms and highly qualified entrepreneurs have little or no economic impact but are merely indicators for the educational infrastructure. However, little is currently known about such interdependencies and research is required which particularly 


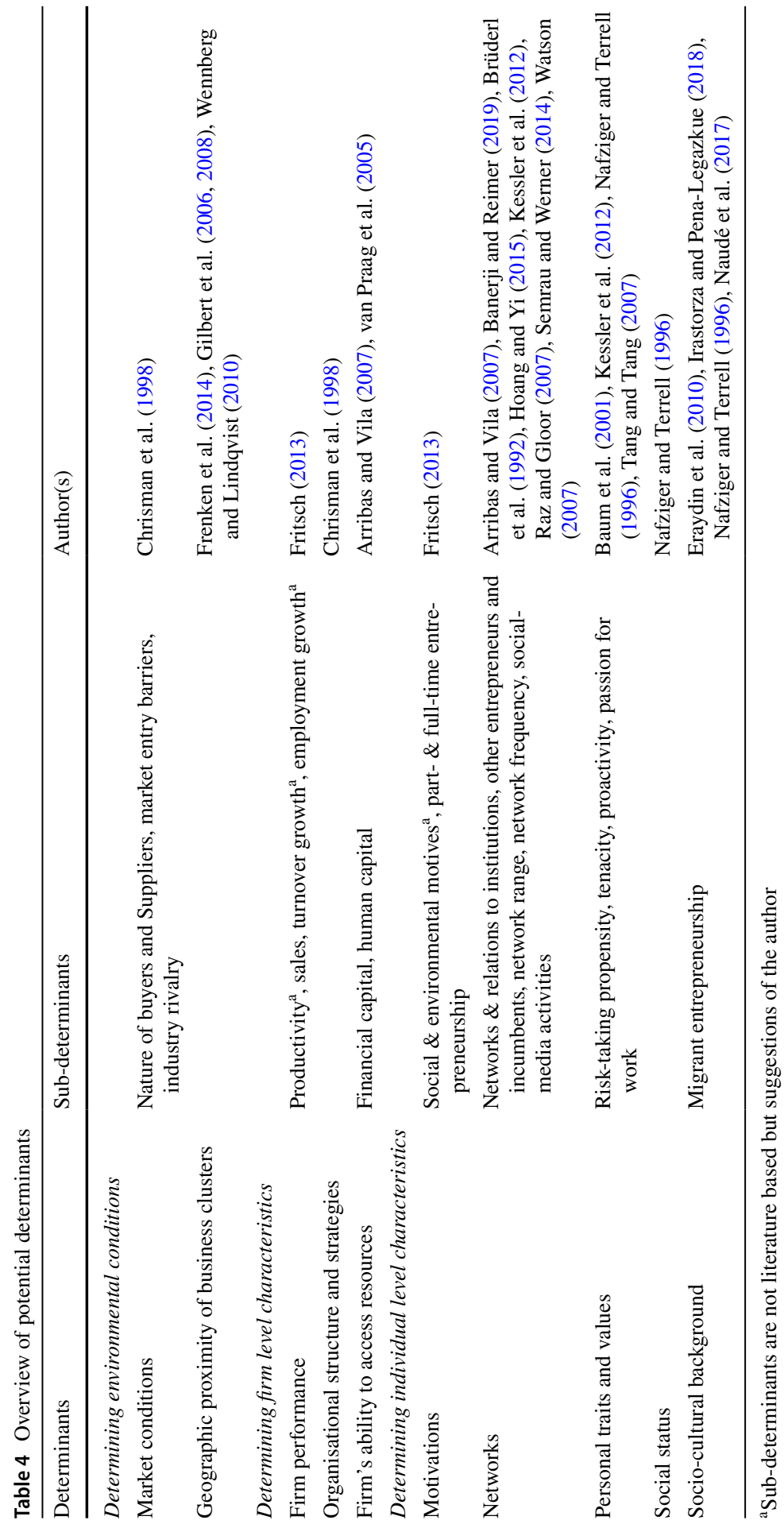


studies the path dependencies behind the impact of entrepreneurship. This is why future empirical research should examine determinants which are supposed to be interdependent as well as external effects which may be related to the determinants of interest.

\section{Limitations and conclusion}

This paper has shed light on the impact of entrepreneurship on economic welfare and the determinants of this impact, but it is not without limitations. First, this paper seeks to give a comprehensive overview of the empirical research, but the search was limited by a variety of in- and exclusion criteria as well as by the terms used in the search string. Although the exclusive focus on peer-reviewed articles is common practice in systematic literature reviews, this may have led to the systematic exclusion of potentially relevant research outcomes, e.g. from dissertation, book chapters, conference contributions or working papers. Furthermore, it is possible that individual studies were not identified by the automated search for the search string in keywords, titles and abstracts. These limitations were necessary to reduce the search results to a manageable level and to ensure a certain quality of the results. The additional screening of key journals, meta-studies and reviews as well as the applied back- and forward snowballing approach, however, weaken the effects of these limitations. Second, this paper only deals with empirical studies. The inclusion of qualitative studies might have revealed further studies dealing with the impact of entrepreneurship on environmental and social welfare. Additionally, the exclusion of qualitative studies limits the analytical depth within the discussion of the determinants. Third, the paper focused on research on a few selected measures of entrepreneurship. In doing so, intrapreneurship, entrepreneurship culture or diverse composed entrepreneurial activity measures of entrepreneurship were excluded. Fourth, it needs to be stated that large parts of the data selection and synthesis were only conducted by the author. Although the chosen procedure and the frequent consultation with the research panel reduced the likelihood of biases, the chance remains that the review is burdened with subjectivity and selection biases. Finally, the scope of this paper was to provide a first descriptive summary of the determinants analysed in the empirical literature and to derive research recommendation. Due to this clear focus this paper does not comprise extensive bibliometric- or meta-analyses that describe in detail the general literature on the impact of entrepreneurship.

The systematic review presented in this paper was conducted for three main reasons. First, to summarize the current state of empirical research on the impact of entrepreneurship on economic, social and environmental welfare. Second, to identify the determinants of this impact and third, to develop a roadmap for future research. Due to the application of a broad entrepreneurship definition and due to the incorporation of economic, social and environmental welfare, this paper presents the most comprehensive overview, summary and synthesis of empirical research on this topic to date. The results confirm the findings and theories of previous literature reviews on the impact of entrepreneurship, provide an update and extension to the current knowledge and finally, represent a first attempt to structure the determinants 
of the impact of entrepreneurship. The new determinants-driven perspective on the research field reveals several shortcomings that would otherwise have gone unnoticed. The developed roadmap for future research — combined with a higher variety of applied measures of entrepreneurship and with an increased awareness of causality and interdependency issues-will allow future researchers to unravel the complex relationship between entrepreneurship and welfare and therewith to provide politicians the comprehensive information they need to promote the right types of entrepreneurship in the right situations.

Acknowledgements Open Access funding provided by Projekt DEAL. I like to thank Dirk Ludewig, of the Flensburg University of Applied Sciences and Olav Hohmeyer, of the Europa-Universität Flensburg, for their useful and valuable feedback on previous versions of this paper. Furthermore, I would like to express my appreciation to the participants of the G-Forum conference in Wien, Austria (September, 2019) and of the paper development workshop of the FGF e.V. working group on sustainable entrepreneurship in Flensburg, Germany (March, 2020), where earlier versions of the paper were discussed.

Funding Not applicable.

\section{Compliance with ethical standards}

Conflict of interest The author declares that he has no conflict of interest.

Open Access This article is licensed under a Creative Commons Attribution 4.0 International License, which permits use, sharing, adaptation, distribution and reproduction in any medium or format, as long as you give appropriate credit to the original author(s) and the source, provide a link to the Creative Commons licence, and indicate if changes were made. The images or other third party material in this article are included in the article's Creative Commons licence, unless indicated otherwise in a credit line to the material. If material is not included in the article's Creative Commons licence and your intended use is not permitted by statutory regulation or exceeds the permitted use, you will need to obtain permission directly from the copyright holder. To view a copy of this licence, visit http://creativecommons.org/licen ses/by/4.0/.

\section{References}

Abdesselam R, Bonnet J, Renou-Maissant P (2014) Typology of the French regional development: revealing the refugee versus Schumpeter effects in new-firm start-ups. Appl Econ 46:3437-3451. https://doi.org/10.1080/00036846.2014.931920

Acs ZJ, Armington C (2004) Employment growth and entrepreneurial activity in cities. Reg Stud 38:911927. https://doi.org/10.1080/0034340042000280938

Acs ZJ, Mueller P (2008) Employment effects of business dynamics: mice, gazelles and elephants. Small Bus Econ 30:85-100. https://doi.org/10.1007/s11187-007-9052-3

Acs ZJ, Varga A (2005) Entrepreneurship, agglomeration and technological change. Small Bus Econ 24:323-334. https://doi.org/10.1007/s11187-005-1998-4

Acs ZJ, Braunerhjelm P, Audretsch DB, Carlsson B (2009) The knowledge spillover theory of entrepreneurship. Small Bus Econ 32:15-30. https://doi.org/10.1007/s11187-008-9157-3

Acs ZJ, Audretsch DB, Braunerhjelm P, Carlsson B (2012) Growth and entrepreneurship. Small Bus Econ 39:289-300. https://doi.org/10.1007/s11187-010-9307-2

Acs ZJ, Audretsch DB, Lehmann EE (2013) The knowledge spillover theory of entrepreneurship. Small Bus Econ 41:757-774. https://doi.org/10.1007/s11187-013-9505-9

Adusei M (2016) Does entrepreneurship promote economic growth in Africa? Afr Dev Rev 28:201-214. https://doi.org/10.1111/1467-8268.12190 
Albulescu CT, Draghici A (2016) Entrepreneurial activity and national innovative capacity in selected European countries. Int J Entrep Innov 17:155-172. https://doi.org/10.1177/1465750316655902

Alvarez SA, Barney JB (2014) Entrepreneurial opportunities and poverty alleviation. Entrep Theory Pract 38:159-184. https://doi.org/10.1111/etap.12078

Andersson M, Noseleit F (2011) Start-ups and employment dynamics within and across sectors. Small Bus Econ 36:461-483. https://doi.org/10.1007/s11187-009-9252-0

Andersson M, Braunerhjelm P, Thulin P (2012) Creative destruction and productivity: entrepreneurship by type, sector and sequence. J Entrep Public Policy 1:125-146. https://doi.org/10.1108/20452 101211261417

Anokhin S, Wincent J (2012) Start-up rates and innovation: a cross-country examination. J Int Bus Stud 43:41-60. https://doi.org/10.1057/jibs.2011.47

Aparicio S, Urbano D, Audretsch D (2016) Institutional factors, opportunity entrepreneurship and economic growth: panel data evidence. Technol Forecast Soc Change 102:45-61. https://doi. org/10.1016/j.techfore.2015.04.006

Apergis N, Payne JE (2016) An empirical note on entrepreneurship and unemployment: further evidence from U.S. states. J Entrep Public Policy 5:73-81. https://doi.org/10.1108/JEPP-10-2015-0029

Arribas I, Vila JE (2007) Human capital determinants of the survival of entrepreneurial service firms in Spain. Int Entrep Manag J 3:309-322. https://doi.org/10.1007/s11365-007-0038-Z

Ashcroft B, Love JH (1996) Firm births and employment change in the British counties: 1981-89. Pap Reg Sci 75:483-500. https://doi.org/10.1111/j.1435-5597.1996.tb00675.x

Atems B, Shand G (2018) An empirical analysis of the relationship between entrepreneurship and income inequality. Small Bus Econ 51:905-922. https://doi.org/10.1007/s11187-017-9984-1

Audretsch DB, Fritsch M (2003) Linking entrepreneurship to growth: the case of West Germany. Ind Innov 10:65-73. https://doi.org/10.1080/1366271032000068104

Audretsch DB, Keilbach M (2004a) Entrepreneurship capital and economic performance. Reg Stud 38:949-959. https://doi.org/10.1080/0034340042000280956

Audretsch DB, Keilbach M (2004b) Entrepreneurship and regional growth: an evolutionary interpretation. J Evol Econ 14:605-616. https://doi.org/10.1007/s00191-004-0228-6

Audretsch DB, Keilbach M (2004c) Does entrepreneurship capital matter? Entrep Theory Pract 28:419-429. https://doi.org/10.1111/j.1540-6520.2004.00055.x

Audretsch DB, Keilbach M (2005) Entrepreneurship capital and regional growth. Ann Reg Sci 39:457-469. https://doi.org/10.1007/s00168-005-0246-9

Audretsch DB, Keilbach M (2008) Resolving the knowledge paradox: knowledge-spillover entrepreneurship and economic growth. Res Policy 37:1697-1705. https://doi.org/10.1016/j.respo 1.2008.08.008

Audretsch DB, Boente W, Keilbach M (2008) Entrepreneurship capital and its impact on knowledge diffusion and economic performance. J Bus Ventur 23:687-698. https://doi.org/10.1016/j.jbusv ent.2008.01.006

Audretsch DB, Belitski M, Desai S (2015) Entrepreneurship and economic development in cities. Ann Reg Sci 55:33-60. https://doi.org/10.1007/s00168-015-0685-x

Banerji D, Reimer T (2019) Startup founders and their LinkedIn connections: are well-connected entrepreneurs more successful? Comput Hum Behav 90:46-52. https://doi.org/10.1016/j. chb.2018.08.033

Baptista R, Preto MT (2010) Long-term effects of new firm formation by type of start-up. Int J Entrep Small Bus 11:382-402. https://doi.org/10.1504/IJESB.2010.036293

Baptista R, Preto MT (2011) New firm formation and employment growth: regional and business dynamics. Small Bus Econ 36:419-442. https://doi.org/10.1007/s11187-009-9254-y

Baptista R, Escária V, Madruga P (2008) Entrepreneurship, regional development and job creation: the case of Portugal. Small Bus Econ 30:49-58. https://doi.org/10.1007/s11187-007-9055-0

Bashir S, Gebremedhin T (2011) An analysis of the relationship between new firm formation and economic development in the northeast region of the United States. J Dev Entrep 16:289-306. https ://doi.org/10.1142/S1084946711001859

Baum JR, Smith KG, Locke EA (2001) A multidimensional model of venture growth. Acad Manag J 44:292-303. https://doi.org/10.2307/3069456

Belitski M, Desai S (2016) Creativity, entrepreneurship and economic development: city-level evidence on creativity spillover of entrepreneurship. J Technol Transf 41:1354-1376. https://doi. org/10.1007/s10961-015-9446-3 
Ben Youssef A, Boubaker S, Omri A (2018) Entrepreneurship and sustainability: the need for innovative and institutional solutions. Technol Forecast Soc Change 129:232-241. https://doi. org/10.1016/j.techfore.2017.11.003

Bjørnskov C, Foss N (2013) How strategic entrepreneurship and the institutional context drive economic growth. Strateg Entrep J 7:50-69. https://doi.org/10.1002/sej.1148

Bjørnskov C, Foss NJ (2016) Institutions, entrepreneurship, and economic growth: what do we know and what do we still need to know? Acad Manag Perspect 30:292-315

Block J, Thurik R, Zhou H (2013) What turns knowledge into innovative products? The role of entrepreneurship and knowledge spillovers. J Evol Econ 23:693-718. https://doi.org/10.1007/s0019 1-012-0265-5

Block JH, Fisch CO, van Praag M (2017) The Schumpeterian entrepreneur: a review of the empirical evidence on the antecedents, behaviour and consequences of innovative entrepreneurship. Ind Innov 24:61-95. https://doi.org/10.1080/13662716.2016.1216397

Bosma N, Stam E, Schutjens V (2011) Creative destruction and regional productivity growth: evidence from the Dutch manufacturing and services industries. Small Bus Econ 36:401-418. https://doi.org/10.1007/s11187-009-9257-8

Braunerhjelm P, Borgman B (2004) Geographical concentration, entrepreneurship and regional growth: evidence from regional data in Sweden, 1975-99. Reg Stud 38:929-947. https://doi. org/10.1080/0034340042000280947

Braunerhjelm P, Acs ZJ, Audretsch DB, Carlsson B (2010) The missing link: knowledge diffusion and entrepreneurship in endogenous growth. Small Bus Econ. https://doi.org/10.1007/s1118 7-009-9235-1

Brixy U (2014) The significance of entry and exit for regional productivity growth. Reg Stud 48:10511070. https://doi.org/10.1080/00343404.2014.895804

Brüderl J, Preisendörfer P, Ziegler R (1992) Survival chances of newly founded business organizations. Am Sociological Rev 57:227. https://doi.org/10.2307/2096207

Carree MA, Thurik RA (2008) The lag structure of the impact of business ownership on economic performance in OECD countries. Small Bus Econ 30:101-110. https://doi.org/10.1007/s1118 7-006-9007-0

Carree M, van Stel A, Thurik R, Wennekers S (2002) Economic development and business ownership: an analysis using data of 23 OECD countries in the period 1976-1996. Small Bus Econ 19:271-290. https://doi.org/10.1023/A:1019604426387

Carree M, van Stel A, Thurik R, Wennekers S (2007) The relationship between economic development and business ownership revisited. Entrep Reg Dev 19:281-291. https://doi.org/10.1080/08985 620701296318

Carree M, Congregado E, Golpe A, van Stel A (2015) Self-employment and job generation in metropolitan areas, 1969-2009. Entrep Reg Dev 27:181-201. https://doi.org/10.1080/08985626.2015.10258 60

Chen CC (2014) Entrepreneurship economic growth and employment: a case study of Taiwan. Hitotsubashi J Econ 55:71-88. https://doi.org/10.15057/26817

Chrisman JJ, Bauerschmidt A, Hofer CW (1998) The determinants of new venture performance: an extended model. Entrep Theory Pract 23:5-29. https://doi.org/10.1177/104225879802300101

Cliff JE (1998) Does one size fit all? Exploring the relationship between attitudes towards growth, gender, and business size. J Bus Ventur 13:523-542. https://doi.org/10.1016/S0883-9026(97)00071-2

Cole IM (2018) Unemployment and entrepreneurship in the Mid-Atlantic Region of the United States: a spatial panel data analysis. Rev Reg Stud 48:347-375

Criscuolo C, Gal PN, Menon C (2017) Do micro start-ups fuel job creation? Cross-country evidence from the DynEmp Express database. Small Bus Econ 48:393-412. https://doi.org/10.1007/s1118 7-016-9778-x

Crnogaj K, Rebernik M, Hojnik BB (2015) Supporting economic growth with innovation-oriented entrepreneurship. Ekonomický časopis 63:395-409

Cumming D, Johan S, Zhang M (2014) The economic impact of entrepreneurship: comparing international datasets. Corp Gov Int Rev 22:162-178. https://doi.org/10.1111/corg.12058

Daly HE, Cobb JB, Cobb CW (1994) For the common good: redirecting the economy toward community, the environment, and a sustainable future/Herman E. Daly and John B. Cobb, Jr.; with contributions by Clifford W. Cobb, 2nd ed., updated and expanded. Beacon Press, Boston

Delfmann H, Koster S (2016) The effect of new business creation on employment growth in regions facing population decline. Ann Reg Sci 56:33-54. https://doi.org/10.1007/s00168-015-0738-1 
Dhahri S, Omri A (2018) Entrepreneurship contribution to the three pillars of sustainable development: what does the evidence really say? World Dev 106:64-77. https://doi.org/10.1016/j.world dev.2018.01.008

Dixon-Woods M, Agarwal S, Jones D, Young B, Sutton A (2005) Synthesising qualitative and quantitative evidence: a review of possible methods. J Health Serv Res Policy 10:45-53. https://doi. org/10.1258/1355819052801804

Doran J, McCarthy N, O'Connor M (2016) Entrepreneurship and employment growth across European regions. Reg Stud Reg Sci 3:121-128. https://doi.org/10.1080/21681376.2015.1135406

Draghici A, Albulescu CT (2014) Does the entrepreneurial activity enhance the national innovative capacity? Procedia Soc Behav Sci 124:388-396. https://doi.org/10.1016/j.sbspro.2014.02.500

Du K, O’Connor A (2017) Entrepreneurship and advancing national level economic efficiency. Small Bus Econ 50:91-111. https://doi.org/10.1007/s11187-017-9904-4

Dvouletý O (2017) Can policy makers count with positive impact of entrepreneurship on economic development of the Czech regions? J Entrep Emerg Econ 9:286. https://doi.org/10.1108/ JEEE-11-2016-0052

Engel D, Metzger G (2006) Direct employment effects of new firms. In: Fritsch M, Schmude J (eds) Entrepreneurship in the region, vol 49. Springer, Boston, pp 75-93

Eraydin A, Tasan-Kok T, Vranken J (2010) Diversity matters: immigrant entrepreneurship and contribution of different forms of social integration in economic performance of cities. Eur Plan Stud 18:521-543. https://doi.org/10.1080/09654311003593556

Erken H, Donselaar P, Thurik R (2018) Total factor productivity and the role of entrepreneurship. J Technol Transf 43:1493-1521. https://doi.org/10.1007/s10961-016-9504-5

Falck O (2007) Mayflies and long-distance runners: the effects of new business formation on industry growth. Appl Econ Lett 14:919-922. https://doi.org/10.1080/13504850600705877

Fayolle A, Wright M (2014) How to get published in the best entrepreneurship journals: a guide to steer your academic career/edited by Alain Fayolle and Mike Wright. Edward Elgar, Cheltenham

Feki C, Mnif S (2016) Entrepreneurship, technological innovation, and economic growth: empirical analysis of panel data. J Knowl Econ 7:984-999. https://doi.org/10.1007/s13132-016-0413-5

Ferreira JJ, Fayolle A, Fernandes C, Raposo M (2017) Effects of Schumpeterian and Kirznerian entrepreneurship on economic growth: panel data evidence. Entrep Reg Dev 29:1-27. https://doi. org/10.1080/08985626.2016.1255431

Fisch C, Block J (2018) Six tips for your (systematic) literature review in business and management research. Manag Rev Q 68:103-106. https://doi.org/10.1007/s11301-018-0142-X

Fölster S (2000) Do entrepreneurs create jobs? Small Bus Econ 14:137-148. https://doi. org/10.1023/A:1008141516160

Frenken K, Cefis E, Stam E (2014) Industrial dynamics and clusters: a survey. Reg Stud 49:10-27. https://doi.org/10.1080/00343404.2014.904505

Fritsch M (1996) Turbulence and growth in West Germany: a comparison of evidence by regions and industries. Rev Ind Organ 11:231-251. https://doi.org/10.1007/BF00157669

Fritsch M (2013) New business formation and regional development: a survey and assessment of the evidence. Found Trends Entrep 9:249-364. https://doi.org/10.1561/0300000043

Fritsch M, Mueller P (2004) Effects of new business formation on regional development over time. Reg Stud 38:961-975. https://doi.org/10.1080/0034340042000280965

Fritsch M, Mueller P (2008) The effect of new business formation on regional development over time: the case of Germany. Small Bus Econ 30:15-29. https://doi.org/10.1007/s11187-007-9067-9

Fritsch M, Noseleit F (2013a) Investigating the anatomy of the employment effect of new business formation. Camb J Econ. https://doi.org/10.1093/cje/bes030

Fritsch M, Noseleit F (2013b) Start-ups, long- and short-term survivors, and their contribution to employment growth. J Evol Econ 23:719-733. https://doi.org/10.1007/s00191-012-0301-5

Fritsch M, Schindele Y (2011) The contribution of new businesses to regional employment-an empirical analysis. Econ Geogr 87:153-180. https://doi.org/10.1111/j.1944-8287.2011.01113.x

Fritsch M, Schroeter A (2011) Why does the effect of new business formation differ across regions? Small Bus Econ 36:383. https://doi.org/10.1007/s11187-009-9256-9

Fryges H, Wagner J (2008) Exports and productivity growth: first evidence from a continuous treatment approach. Rev World Econ 144:695-722. https://doi.org/10.1007/s10290-008-0166-8 
Gast J, Gundolf K, Cesinger B (2017) Doing business in a green way: a systematic review of the ecological sustainability entrepreneurship literature and future research directions. J Clean Prod 147:44-56. https://doi.org/10.1016/j.jclepro.2017.01.065

Gilbert BA, McDougall PP, Audretsch DB (2006) New venture growth: a review and extension. J Manag 32:926-950. https://doi.org/10.1177/0149206306293860

Gilbert BA, McDougall PP, Audretsch DB (2008) Clusters, knowledge spillovers and new venture performance: an empirical examination. J Bus Ventur 23:405-422. https://doi.org/10.1016/j. jbusvent.2007.04.003

Gittell R, Sohl J, Tebaldi E (2014) Do entrepreneurship and high-tech concentration create jobs? Exploring the growth in employment in U.S. metropolitan areas from 1991 to 2007. Econ Dev Q 28:244-253. https://doi.org/10.1177/0891242414530467

González-Pernía J, Peña-Legazkue I (2015) Export-oriented entrepreneurship and regional economic growth. Small Bus Econ 45:505. https://doi.org/10.1007/s11187-015-9657-x

González-Pernía J, Peña-Legazkue I, Vendrell-Herrero F (2012) Innovation, entrepreneurial activity and competitiveness at a sub-national level. Small Bus Econ 39:561-574. https://doi. org/10.1007/s11187-011-9330-y

Hafer RW (2013) Entrepreneurship and state economic growth. J Entrep Public Policy. https://doi. org/10.1108/20452101311318684

Hamdan AMM (2019) Entrepreneurship and economic growth: an Emirati perspective. J Dev Areas 53:65-78. https://doi.org/10.1353/jda.2019.0004

Harmina A (2016) The role of entrepreneurship in explaining the real gross domestic product per capita: regression model selection. Croat Rev Econ Bus Soc Stat 2:297. https://doi.org/10.1515/crebs s-2016-0007

Henderson J, Weiler S (2009) Entrepreneurs and job growth: probing the boundaries of time and space. Econ Dev Q 24:23-32. https://doi.org/10.1177/0891242409350917

Hessels J, van Stel A (2011) Entrepreneurship, export orientation, and economic growth. Small Bus Econ 37:255-268. https://doi.org/10.1007/s11187-009-9233-3

Higgins JPT, Green S (2008) Cochrane handbook for systematic reviews of interventions. Wiley, Chichester

Hoang H, Yi A (2015) Network-based Research in entrepreneurship: a decade in review. Found Trends Entrep 11:1-54. https://doi.org/10.1561/0300000052

Irastorza N, Pena-Legazkue I (2018) Immigrant entrepreneurship and business survival during recession: evidence from a local economy. J Entrep 27:243-257. https://doi.org/10.1177/0971355718781248

Ivanović-Đukić M, Lepojevi V, Stefanovic S, van Stel A, Petrovic J (2018) Contribution of entrepreneurship to economic growth: a comparative analysis of south-east transition and developed European countries. Int Rev Entrep 16:257-276

Jones O, Gatrell C (2014) Editorial: The future of writing and reviewing for IJMR. Int J Manag Rev 16:249-264. https://doi.org/10.1111/ijmr.12038

Jones MV, Coviello N, Tang YK (2011) International entrepreneurship research (1989-2009): a domain ontology and thematic analysis. J Bus Ventur 26:632-659. https://doi.org/10.1016/j.jbusv ent.2011.04.001

Kalleberg AL, Leicht KT (1991) Gender and organizational performance: determinants of small business survival and success. Acad Manag J 34:136-161. https://doi.org/10.5465/256305

Kangasharju A, Pekkala S (2002) The role of education in self-employment success in Finland. Growth Change 33:216-237. https://doi.org/10.1111/0017-4815.00188

Kasseeah H (2016) Investigating the impact of entrepreneurship on economic development: a regional analysis. J Small Bus Enterp Dev. https://doi.org/10.1108/JSBED-09-2015-0130

Kessler A, Korunka C, Frank H, Lueger M (2012) Predicting founding success and new venture survival: a longitudinal nascent entrepreneurship approach. J Enterp Cult 20:25-55. https://doi.org/10.1142/ S0218495812500021

Kirzner IM (1973) Competition and entrepreneurship. University of Chicago Press, Chicago

Koellinger PD, Thurik RA (2012) Entrepreneurship and the business cycle. Rev Econ Stat 94:1143-1156. https://doi.org/10.1162/REST_a_00224

Koster S (2011) Individual foundings and organizational foundings: their effect on employment growth in The Netherlands. Small Bus Econ 36:485-501. https://doi.org/10.1007/s11187-009-9253-z

Koster S, van Stel A (2014) The relationship between start-ups, market mobility and employment growth: an empirical analysis for Dutch regions. Pap Reg Sci 93:203-217. https://doi.org/10.1111/ pirs. 12000 
Lee YS (2017) Entrepreneurship, small businesses and economic growth in cities. J Econ Geogr 17:311343. https://doi.org/10.1093/jeg/lbw021

Li H, Cheng S, Haynes KE (2011) The employment effects of new business formation: a regional perspective. Econ Dev Q 25:282-292. https://doi.org/10.1177/0891242411407310

Li H, Yang Z, Yao X, Zhang H, Zhang J (2012) Entrepreneurship, private economy and growth: evidence from China. China Econ Rev 23:948-961. https://doi.org/10.1016/j.chieco.2012.04.015

Li H, Terjesen S, Umans T (2020) Corporate governance in entrepreneurial firms: a systematic review and research agenda. Small Bus Econ 54:43-74. https://doi.org/10.1007/s11187-018-0118-1

Liargovas P, Repousis S (2013) Development paths in the knowledge economy: innovation and entrepreneurship in Greece. J Knowl Econ 6:1063-1077. https://doi.org/10.1007/s13132-013-0176-1

Matejovsky L, Mohapatra S, Steiner B (2014) The dynamic effects of entrepreneurship on regional economic growth: evidence from Canada. Growth Change 45:611-639. https://doi.org/10.1111/ grow. 12055

McMullen JS (2011) Delineating the domain of development entrepreneurship: a market-based approach to facilitating inclusive economic growth: ET\&P ET\&P. Entrep Theory Pract 35:185193. https://doi.org/10.1111/j.1540-6520.2010.00428.x

Meadows DH, Meadows DL, Randers J, Behrens WW III (1972) The limits to growth: a report for the Club of Rome's project on the predicament of mankind/Donella H. Meadows ... [et al.]. Universe Books, New York

Meyer N, Meyer DF (2017) An econometric analysis of entrepreneurial activity, economic growth and employment: the case of the BRICS countries. Int J Econ Perspect 11:429-441

Mochkabadi K, Volkmann CK (2020) Equity crowdfunding: a systematic review of the literature. Small Bus Econ 54:75-118. https://doi.org/10.1007/s11187-018-0081-x

Mrozewski M, Kratzer J (2017) Entrepreneurship and country-level innovation: investigating the role of entrepreneurial opportunities. J Technol Transf 42:1125-1142. https://doi.org/10.1007/s1096 1-016-9479-2

Mueller P (2007) Exploiting entrepreneurial opportunities: the impact of entrepreneurship on growth. Small Bus Econ 28:355-362. https://doi.org/10.1007/s11187-006-9035-9

Mueller P, van Stel A, Storey DJ (2008) The effects of new firm formation on regional development over time: the case of Great Britain. Small Bus Econ 30:59-71. https://doi.org/10.1007/S1118 7-007-9056-Z

Mulrow CD (1994) Rationale for systematic reviews. BMJ 309:597-599. https://doi.org/10.1136/ bmj.309.6954.597

Munoz P, Cohen B (2018) Sustainable entrepreneurship research: taking stock and looking ahead. Bus Strateg Environ 27:300-322. https://doi.org/10.1002/bse.2000

Nafziger EW, Terrell D (1996) Entrepreneurial human capital and the long-run survival of firms in India. World Dev 24:689-696. https://doi.org/10.1016/0305-750X(95)00161-5

Naudé W, Siegel M, Marchand K (2017) Migration, entrepreneurship and development: critical questions. IZA J Migration 6:5. https://doi.org/10.1186/s40176-016-0077-8

Nissan E, Galindo Martin M-A, Mendez Picazo M-T (2011) Relationship between organizations, institutions, entrepreneurship and economic growth process. Int Entrep Manag J 7:311-324. https://doi.org/10.1007/s11365-011-0191-2

Nordhaus W, Tobin J (1972) Is growth obsolete? Econ Res 5:1-80

North DC (2012) Institutions, institutional change and economic performance. Cambridge University Press, Cambridge

Noseleit F (2013) Entrepreneurship, structural change, and economic growth. J Evol Econ 23:735766. https://doi.org/10.1007/s00191-012-0291-3

Omri A (2017) Entrepreneurship, sectoral outputs and environmental improvement: international evidence. Technol Forecast Soc Change. https://doi.org/10.1016/j.techfore.2017.10.016

Ordanini A, Rubera G, DeFillippi R (2008) The many moods of inter-organizational imitation: a critical review. Int J Manag Rev 10:375-398. https://doi.org/10.1111/j.1468-2370.2008.00233.x

Podsakoff PM, MacKenzie SB, Bachrach DG, Podsakoff NP (2005) The influence of management journals in the 1980s and 1990s. Strateg Manag J 26:473-488. https://doi.org/10.1002/smj.454

Popay J, Roberts H, Sowden A, Petticrew M, Arai L, Rodgers M, Britten N, Roen K, Duffy S (2006) Guidance on the conduct of narrative synthesis in systematic reviews: a product from the ESRC Methods Programme. Lancaster University, Lancaster

Prieger JE, Bampoky C, Blanco LR, Liu A (2016) Economic growth and the optimal level of entrepreneurship. World Dev 82:95-109. https://doi.org/10.1016/j.worlddev.2016.01.013 
Raz O, Gloor PA (2007) Size really matters-new insights for start-ups' survival. Manag Sci 53:169177. https://doi.org/10.1287/mnsc. 1060.0609

Reynolds PD, Bygrave WD, Autio E (2003) Global entrepreneurship Monitor: 2003 executive report. http://www.gemconsortium.org/report/47102. Accessed 27 Dec 2017

Rho S, Gao J (2012) Employment effect of entrepreneurial activity in China's private economy. Seoul J Econ 25:177-206

Rosa P, Carter S, Hamilton D (1996) Gender as a determinant of small business performance: insights from a British study. Small Bus Econ 8:463-478. https://doi.org/10.1007/BF00390031

Rupasingha A, Goetz SJ (2013) Self-employment and local economic performance: evidence from US counties. Pap Reg Sci 92:141. https://doi.org/10.1111/j.1435-5957.2011.00396.x

Sabella A, Farraj W, Burbar M, Qaimary D (2014) Entrepreneurship and economic growth in West Bank, Palestine. J Dev Entrep 19:1. https://doi.org/10.1142/S1084946714500034

Salgado Banda H (2007) Entrepreneurship and economic growth: an empirical analysis. J Dev Entrep 12:3-29. https://doi.org/10.1142/S1084946707000538

Schumpeter JA (1942) Capitalism, socialism and democracy, [Reprint]. Harper colophon, Harper Perennial, New York

Semrau T, Werner A (2014) How exactly do network relationships pay off? The effects of network size and relationship quality on access to start-up resources. Entrep Theory Pract 38:501-525. https:// doi.org/10.1111/etap.12011

Stam E, Hartog C, van Stel A, Thurik R (2011) Ambitious entrepreneurship, high-growth firms, and macroeconomic growth. In: Minniti M (ed) The dynamics of entrepreneurship. Oxford University Press, Oxford

Szerb L, Lafuente E, Horváth K, Páger B (2018) The relevance of quantity and quality entrepreneurship for regional performance: the moderating role of the entrepreneurial ecosystem. Reg Stud. https:// doi.org/10.1080/00343404.2018.1510481

Tang J, Tang Z (2007) The relationship of achievement motivation and risk-taking propensity to new venture performance: a test of the moderating effect of entrepreneurial munificence. Int J Entrep Small Bus 4:450. https://doi.org/10.1504/IJESB.2007.013691

Terán-Yépez E, Marín-Carrillo GM, Casado-Belmonte MP, Capobianco-Uriarte MM (2020) Sustainable entrepreneurship: review of its evolution and new trends. J Clean Prod. https://doi.org/10.1016/j. jclepro.2019.119742

Thurik RA, Carree MA, van Stel A, Audretsch DB (2008) Does self-employment reduce unemployment? J Bus Ventur 23:673-686. https://doi.org/10.1016/j.jbusvent.2008.01.007

Tietenberg TH, Lewis L (2012) Environmental \& natural resource economics. Pearson series in economics, 9th edn. Pearson Education, Upper Saddle River

Tranfield D, Denyer D, Smart P (2003) Towards a methodology for developing evidence-informed management knowledge by means of systematic review. Br J Manag 14:207-222. https://doi. org/10.1111/1467-8551.00375

Unger JM, Rauch A, Frese M, Rosenbusch N (2011) Human capital and entrepreneurial success: a metaanalytical review. J Bus Ventur 26:341-358. https://doi.org/10.1016/j.jbusvent.2009.09.004

Urbano D, Aparicio S (2016) Entrepreneurship capital types and economic growth: International evidence. Technol Forecast Soc Change 102:34-44. https://doi.org/10.1016/j.techfore.2015.02.018

Urbano D, Aparicio S, Audretsch D (2019a) Twenty-five years of research on institutions, entrepreneurship, and economic growth: what has been learned? Small Bus Econ 53:21-49. https://doi. org/10.1007/s11187-018-0038-0

Urbano D, Audretsch D, Aparicio S, Noguera M (2019b) Does entrepreneurial activity matter for economic growth in developing countries? The role of the institutional environment. Int Entrep Manag J 6:875. https://doi.org/10.1007/s11365-019-00621-5

Valliere D, Peterson R (2009) Entrepreneurship and economic growth: evidence from emerging and developed countries. Entrep Reg Dev 21:459-480. https://doi.org/10.1080/08985620802332723

van Oort FG, Bosma NS (2013) Agglomeration economies, inventors and entrepreneurs as engines of European regional economic development. Ann Reg Sci 51:213-244. https://doi.org/10.1007/ s00168-012-0547-8

van Praag CM, Versloot PH (2007) What is the value of entrepreneurship? A review of recent research. Small Bus Econ 29:351-382. https://doi.org/10.1007/s11187-007-9074-x

van Praag CM, Wit GD, Bosma N (2005) Initial capital constraints hinder entrepreneurial venture performance. J Priv Equity 9:36-44. https://doi.org/10.3905/jpe.2005.605369 
van Stel A, Storey D (2004) The link between firm births and job creation: is there a Upas Tree effect? Reg Stud 38:893-909. https://doi.org/10.1080/0034340042000280929

van Stel A, Suddle K (2008) The impact of new firm formation on regional development in the Netherlands. Small Bus Econ 30:31-47. https://doi.org/10.1007/s11187-007-9054-1

van Stel A, Carree M, Thurik R (2005) The effect of entrepreneurial activity on national economic growth. Small Bus Econ 24:311-321. https://doi.org/10.1007/s11187-005-1996-6

Vázquez-Rozas E, Gómes S, Viera E (2010) Entrepreneurship and economic growth in Spanish and Portuguese regions. Reg Sect Econ Stud 10:109-126

Verheul I, van Stel A (2010) Entrepreneurial diversity and economic growth. In: van Auken H, Bonnet J, García Pérez De Lima D (eds) The entrepreneurial society. Edward Elgar Publishing, Cheltenham

Watson J (2007) Modeling the relationship between networking and firm performance. J Bus Ventur 22:852-874. https://doi.org/10.1016/j.jbusvent.2006.08.001

Wennberg K, Lindqvist G (2010) The effect of clusters on the survival and performance of new firms. Small Bus Econ 34:221-241. https://doi.org/10.1007/s11187-008-9123-0

Wennekers S, Thurik R (1999) Linking entrepreneurship and economic growth. Small Bus Econ 13:27. https://doi.org/10.1023/A:1008063200484

Williams CC, Lansky MA (2013) Informal employment in developed and developing economies: perspectives and policy responses. Int Labour Rev 152:355-380. https://doi.org/10.1111/j.1564913X.2013.00196.x

Wohlin C (2014) Guidelines for snowballing in systematic literature studies and a replication in software engineering. In: Shepperd M, Hall T, Myrtveit I (eds) Proceedings of the 18th international conference on evaluation and assessment in software engineering-EASE '14. ACM Press, New York, pp 1-10

Wong PK, Ho YP, Autio E (2005) Entrepreneurship, innovation and economic growth: evidence from GEM data. Small Bus Econ 24:335-350. https://doi.org/10.1007/s11187-005-2000-1

World Commission on Environment and Development (1987) Brundtland report: our common future. Oxford University Press, Oxford

Zhao S (2018) Entrepreneurship and economic growth during china's economic transformation, 19782008. Seoul J Econ 31:307-331

Publisher's Note Springer Nature remains neutral with regard to jurisdictional claims in published maps and institutional affiliations.

\section{Affiliations}

\section{Thomas Neumann ${ }^{1}$}

1 Faculty of economics, Flensburg University of Applied Sciences, Kanzleistraße 91-93,

Flensburg, Germany 